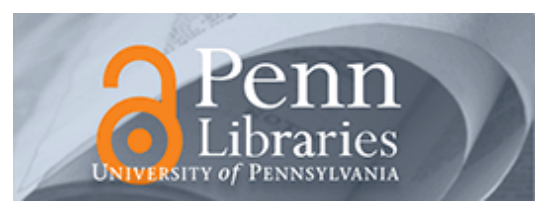

Manuscript Studies

Volume 1

Issue 1 Spring 2017

Article 5

2017

\title{
Towards a Universal Catalogue of Early Manuscripts: Seymour de Ricci's Census of Medieval and Renaissance Manuscripts in the United States and Canada
}

Nigel Ramsay

University College London, n.ramsay@ucl.ac.uk

Follow this and additional works at: https://repository.upenn.edu/mss_sims

Part of the Medieval Studies Commons

\section{Recommended Citation}

Ramsay, Nigel (2017) "Towards a Universal Catalogue of Early Manuscripts: Seymour de Ricci's Census of Medieval and Renaissance Manuscripts in the United States and Canada," Manuscript Studies: Vol. 1 : Iss. 1 , Article 5.

Available at: https://repository.upenn.edu/mss_sims/vol1/iss1/5

This paper is posted at ScholarlyCommons. https://repository.upenn.edu/mss_sims/vol1/iss1/5

For more information, please contact repository@pobox.upenn.edu. 


\title{
Towards a Universal Catalogue of Early Manuscripts: Seymour de Ricci's Census of Medieval and Renaissance Manuscripts in the United States and Canada
}

\author{
Abstract \\ Seymour de Ricci's Census of Medieval and Renaissance Manuscripts in the United States and Canada, \\ published by the Library of Congress in two volumes in 1935 and 1937 respectively, is a fundamental \\ reference for the history of manuscripts in North American institutions and collections. This article \\ explores the history of the Census' production, in particular the challenges that De Ricci faced in \\ completing the monumental task of creating a union catalogue of manuscripts before the dawn of the \\ digital age.
}

\section{Keywords}

Seymour de Ricci, Library of Congress, manuscript cataloging, bibliography, history of collecting, provenance, American manuscript collections, manuscript studies, history of libraries, information science 
Ramsay: Towards a Universal Catalogue of Early Manuscripts

\title{
MANUSCRIPT STUDIES
}

A Journal of the Schoenberg Institute for Manuscript Studies

VOLUME 1, NUMBER 1

(Spring 2016)

\begin{abstract}
Manuscript Studies (ISSN 2381-5329) is published semiannually
by the University of Pennsylvania Press
\end{abstract}

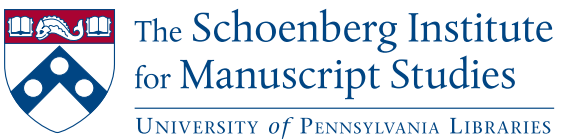




\title{
Manuscript Studies, Vol. 1 [2017], Iss. 1, Art. 5
}

\section{MANUSCRIPT STUDIES}

\author{
VOLUME 1, N U MBER 1
}

(Spring 2016)

ISSN 2381-5329

Copyright (C) 2016 University of Pennsylvania Libraries and University of Pennsylvania Press. All rights reserved.

Published by the University of Pennsylvania Press, 3905 Spruce Street, Philadelphia, PA 19104.

Printed in the U.S.A. on acid-free paper.

Manuscript Studies brings together scholarship from around the world and across disciplines related to the study of premodern manuscript books and documents, with a special emphasis on the role of digital technologies in advancing manuscript research. Articles for submission should be prepared according to the Chicago Manual of Style, $16^{\text {th }}$ edition, and follow the style guidelines found at http://mss.pennpress.org.

None of the contents of this journal may be reproduced without prior written consent of the University of Pennsylvania Press. Authorization to photocopy is granted by the University of Pennsylvania Press for libraries or other users registered with Copyright Clearance Center (CCC) Transaction Reporting Service, provided that all required fees are verified with CCC and paid directly to CCC, 222 Rosewood Drive, Danvers, MA 01923. This consent does not extend to other kinds of copying for general distribution, for advertising or promotional purposes, for creating new collective works, for database retrieval, or for resale.

\section{SUBSCRIPTION INFORMATION:}

Single issues: $\$ 30$

Print and online subscriptions: Individuals: $\$ 40$; Institutions: \$90; Full-time Students: $\$ 30$ International subscribers, please add $\$ 18$ per year for shipping.

Online-only subscriptions: Individuals: $\$ 32$; Institutions: $\$ 78$

Please direct all subscription orders, inquiries, requests for single issues, address changes, and other business communications to Penn Press Journals, 3905 Spruce Street, Philadelphia, PA 19104. Phone: 215-573-1295. Fax: 215-746-3636. Email: journals@pobox.upenn.edu. Prepayment is required. Orders may be charged to MasterCard, Visa, and American Express credit cards. Checks and money orders should be made payable to "University of Pennsylvania Press" and sent to the address printed directly above.

One-year subscriptions are valid January 1 through December 31. Subscriptions received after October 31 in any year become effective the following January 1 . Subscribers joining midyear receive immediately copies of all issues of Manuscript Studies already in print for that year.

Postmaster: send address changes to Penn Press Journals, 3905 Spruce Street, Philadelphia, PA 19104.

Visit Manuscript Studies on the web at mss.pennpress.org. 


\title{
Towards a Universal Catalogue of Early Manuscripts
}

\author{
Seymour de Ricci's Census of Medieval and \\ Renaissance Manuscripts in the United States and Canada
}

\author{
Nigel RAMSAY \\ University College London
}

\begin{abstract}
The decade after the end of the First World War saw the undertaking of a whole raft of bibliographic ventures that were international in their scope. ${ }^{1}$ They ranged from a catalogue of early printed books in the English language-the Short-Title Catalogue of Books Printed in England, Scotland, \& Ireland and of English Books Printed Abroad, 1475-1640 (1926) — to union lists of contemporary scientific periodicals. Also, the international union catalogue of incunables, the Gesamtkatalog der Wiegendrucke, finally came to fruition with the publication of its first volume in 1925.
\end{abstract}

1 The present article has developed out of a long-term study of de Ricci's scholarly activities; I am very grateful to Lynn Ransom and the Schoenberg Institute for Manuscript Studies for inviting me to present a summary version of it at the 7 th Annual Schoenberg Symposium for Manuscript Studies in the Digital Age, held 6-8 November 2014 at the University of Pennsylvania Libraries.

Principal sources for the paper have been the Annual Reports of the Librarian of Congress and the Bulletins of the American Council of Learned Societies, supplemented by the archives of the Library of Congress (especially those boxes with papers relating to Project C, in the Archive of the MSS Division, and Central Files, Putnam-McLeish, Box 59) and the archive of the American Council of Learned Societies; both these archives are housed in the Manuscripts Division of the Library of Congress. 
Even medieval manuscripts benefited from this spirit of interlibrary cooperation, nationally and internationally: for instance, the Union Académique Internationale promoted the compilation of a series of catalogues of alchemical manuscripts in each of several European countries as well as in the USA. It was in this context and thanks to the rather-more-fortuitous combination of certain individuals being in influential posts in the American Council of Learned Societies and the Library of Congress that a union catalogue of foreign manuscripts in the USA was proposed. The appearance on the scene of the Anglo-French scholar Seymour de Ricci then made possible the astonishing achievement of the compilation and publication within little more than ten years of a complete guide to all the medieval and Renaissance manuscripts in the USA and Canada, in private hands as well as in public institutions.

Charles Samaran once described Seymour de Ricci (1881-1942) as a second Pico della Mirandola. ${ }^{2} \mathrm{He}$ was a genius of so many talents that it was hard for contemporaries to grasp what they all were. He had begun as an epigrapher, publishing repertories of Roman inscriptions, when still only in his teens; he was said to have corrected proofs of Theodor Mommsen's Corpus Inscriptionum Latinarum while sitting at the back of his school classroom in Paris. He had also become an Egyptologist: encouraged by the friendship received from the collector and museum-founder Émile Guimet, he began writing a stream of articles about Coptic texts from Egypt, before starting fresh interests in numismatics, early typography, and the history of Western art generally. Each of his interests he took to the level of scholarly publication, and he was barely out of his teens when he settled on his preferred approach to a topic: that of creating a repertory in which he traced the history of each item of a particular category. In 1906 he published a Census of Caxtons; in 1911, a Catalogue raisonné des premières impressions de Mayence (1445-1467); in 1912, a major revision of Henri Cohen's Guide de l'amateur des livres à gravures $d u$ XVIIIe siècle. It was a scholarly approach that

2 For a sketch of de Ricci's life, see N. L. Ramsay, "Ricci, Seymour Montefiore Robert Rosso de (1881-1942)," in The Oxford Dictionary of National Biography, ed. H. C. G. Matthew and Brian Harrison, 60 vols. (Oxford: Oxford University Press, 2004), 46:638-40. 


\section{Ramsay: Towards a Universal Catalogue of Early Manuscripts}

Ramsay, Towards a Universal Catalogue of Early Manuscripts | 73

one of his principal patrons and encouragers, the polymath Salomon Reinach (1858-1932), had made his own name by, through his multi-volume Répertoire de la statuaire grecque et romaine (1897 and later). ${ }^{3}$ In each of these repertories or censuses, de Ricci made the fullest use of dealers' and auction saleroom catalogues, of which he had set about forming his own collection. By the time of his death he had some seventy thousand catalogues.

By the 1920s, de Ricci was at his peak of scholarly activity, lecturing and, above all, writing: articles and books flowed from his pen every month, at times even every week. In 1924, he produced A Catalogue of Early English Books in the Library of John L. Clawson, and in 1927, both A Bibliography of Shelley's Letters, Published and Unpublished and A Catalogue of Early Italian Majolica in the Collection of Mortimer L. Schiff. From 1929, he was also the Paris art correspondent for the New York Herald. At the same time, however, he was doing more than just carrying out the research for these published works: he was also preparing vast numbers of file cards (or rather, slips of paper, cut to his preferred size) on which he entered detailed information about specific items (coins, medals, manuscripts, printed books, bindings, and so forth) that was often drawn from sale and other catalogues. He was building up a vast system, and was in effect creating a resource that was looking for a justification for its existence.

\section{Towards a Union Catalogue of Medieval and Renaissance Manuscripts in the USA}

The notion of a union catalogue of all the medieval manuscripts in the USA was considered by the American Council of Learned Societies in 1925. ${ }^{4}$ There is no reason to think that de Ricci was party to this, but he

3 Salomon Reinach, Répertoire de la statuaire grecque et romaine, 6 vols. in 8 parts (Paris: Leroux, 1904-1930 [1897-1930]); 2nd ed. of vols. 1-4 (Paris, 1906-1913); 3rd ed. of vol. 1 (Paris, 1916).

4 See, for example, "Memorandum on a Catalogue of Foreign Manuscripts in American Libraries and Collections," Bulletin of the American Council of Learned Societies 4

(1925): 50-1. The committee that was set up to oversee this proposed catalogue was ini- 
certainly had had various contacts among American academics, librarians, and curators ever since 1918, when he first came to the States as part of a quasi-governmental mission led by Théodore Reinach-French politician, scholar, editor, member of the Institut de France, and his close friend. In 1927, de Ricci presented his own plan for a universal catalogue of manuscripts to a meeting of the Académie des Inscriptions et Belles-Lettres of the Institut de France. In this address-which he had printed, privately, so that it could be circulated more widely-he recalled that Henri Omont, Keeper of Manuscripts at the Bibliothèque nationale in Paris, had proposed a universal catalogue of Greek manuscripts some thirty years previously, and he also referred to the contemporary plans of Ernest Cushing Richardson, formerly Librarian of Princeton University and currently Honorary Consultant to the Library of Congress. ${ }^{5}$ Richardson was termed Honorary because he declined to take more than a nominal salary (one dollar a month) from the Library, but he was in fact a man of enormous influence there, as will be seen below. ${ }^{6}$

Credit must be given above all others to Waldo Leland, Permanent Secretary of the American Council of Learned Societies, for setting up the scheme that resulted in the compilation and publication of Seymour de Ricci's Census. The American literary scholar, Karl Young, met de Ricci in Paris in the summer of 1928; but a more crucial meeting was that of Leland and de Ricci, also in Paris, in May 1929. It was agreed then that de Ricci would come to America for a series of research trips, the first being for three or four months, beginning in December 1929. He would base himself at the Grolier Club in New York, but would also go across the States to the Huntington Library in San Marino, California. Before this, an assistant, Dr. William Jerome Wilson, would dispatch some four thousand letters of

tially chaired by Prof. Karl Young.

5 S. de Ricci, Projet d'une Bibliotheca Manuscriptorum Nova: Communication faite à l'Académie des Inscriptions ... le 5 Août 1927 (Paris: privately printed, 1927).

6 There is a full-length biography, though inadequate, of Richardson: Lewis C. Branscomb, Ernest Cushing Richardson: Research Librarian, Scholar, Theologian, 1860-1939 (Metuchen, NJ: Scarecrow, 1993); see especially chapter 3 (pp. 37-65) for his involvement with the Library of Congress. 


\section{Ramsay: Towards a Universal Catalogue of Early Manuscripts}

Ramsay, Towards a Universal Catalogue of Early Manuscripts | 75

enquiry to institutions and private individuals in all parts of the US who were potential owners of relevant materials. The whole project was to be based at the Library of Congress in Washington, DC. This was perhaps the most ingenious part of the planning of the whole venture-every bit as important as the basic funding from the General Education Board-for it gave the project credibility with all the collectors and libraries to whom Wilson wrote. Large numbers of both institutional and private owners proved very ready to send their manuscripts on loan to the Library of Congress (the costs of dispatch and insurance were met by the project) so that de Ricci could actually accomplish a great deal from his base within the Library. ${ }^{7}$

\section{The Library of Congress and the Census}

The Librarian of Congress has a very high degree of autonomy, and is appointed for life. Each Librarian has therefore tended to hold office for a great many years and has shaped the Library in accordance with his own wishes. For the forty years from 1899 to 1939, Herbert Putnam was Librarian. It was fortunate for the American Council of Learned Societies and de Ricci that Putnam was an expansionist who wanted the Library to reach out far beyond its basic role as the library that serves the members of Congress.

Putnam achieved his aims partly by buying foreign books: that was the classic way to build up a research library. For instance, in 1906 he bought the eighty-thousand-volume library of Russian literature belonging to G. V. Yudin of Siberia and even sent a member of the Library staff to Siberia to supervise the packing and dispatch of this collection. After the First World War, Putnam began to look to broadening the Library's role beyond the simple purchase of books, using outside funding to help achieve this. For instance, in 1924, the Library began to organize chamber music performances, subvented by Elizabeth Sprague Coolidge, who shortly afterwards

7 The Librarian of Congress also used his contacts to arrange that the proofs and other important postal items were at times despatched from Washington to de Ricci in Paris in the diplomatic pouch: this was speedy as well as secure. 
also paid for the construction of a concert hall. Within a few years the Library was also given five Stradivarius instruments, and it had embarked on an enduring program of hosting musical events. With the establishment of the US National Archives (1934), the Library lost its lead role in the preservation of the nation's archival documentation; but this was more than counterbalanced by a whole range of advances in other areas. ${ }^{8}$

In 1927, the oil magnate John D. Rockefeller, Jr. undertook to fund a five-year project, giving a total of $\$ 700,000$. There were two elements to the venture, the first being the acquisition of photographic copies and facsimiles of source materials for American history that were held in British, French, and other foreign archives. The Canadian national archives, at Ottawa, had already embarked on such a campaign of transcript-gathering, but the use of photography would make the US plan a much more satisfactory undertaking. The Carnegie Institution of Washington had already funded a series of published surveys of such materials; Waldo Leland himself was one of the scholars engaged in this undertaking, having worked for some years on the survey of materials in the libraries of Paris. ${ }^{9}$

The second element of the Rockefeller project was the compilation of an amalgamated card catalogue of all the printed book holdings of the major US libraries-what would later become the National Union Catalog. These two schemes were known within the Library of Congress as Project A and Project B. Each followed a carefully mapped timetable, was closely directed, and was demonstrably successful, although it was of course far easier to

8 Perhaps the clearest overview of the expansion of activities of the Library in these years is to be seen in John Y. Cole, For Congress and the Nation: A Chronological History of the Library of Congress (Washington, DC: Library of Congress, 1979).

9 Waldo G. Leland, Guide to Materials for American History in the Libraries and Archives of Paris, vol. 1 (Washington, DC: Carnegie Institution of Washington, 1932). Leland's method was in many ways comparable to that of the Census, with introductory headnotes about the history of each library's collection and with cross-references to editions of the texts as well as to secondary literature (although with almost nothing about individual provenances). It was based on the sifting through of a vast number of catalogues and manuscripts, in thirteen libraries. As head of the Carnegie Institution's historical mission in Paris, Leland had been resident there for much of the years 1907-1914 and 1922-1927: Who Was Who in America, vol. 4, 1961-1968 (Chicago: Marquis Who's Who, 1968), s.v. Leland. 


\section{Ramsay: Towards a Universal Catalogue of Early Manuscripts}

Ramsay, Towards a Universal Catalogue of Early Manuscripts | 77

show this in the case of Project B, the union catalogue, where the sheer number of cards (cumulatively, in the hundreds of millions) added up as their testimonial. Project B was directed by Ernest C. Richardson.

Richardson had himself proposed a union catalogue of foreign manuscripts in the US, and in 1927 he oversaw the publication of a guide to "Special Collections" in North American libraries. Subsequently, he edited and in part directly compiled a six-volume Union World Catalog of Manuscript Books. ${ }^{10}$ From 1925, he was termed "Honorary Consultant in Bibliography and Research" at the Library of Congress; he clearly had Putnam's ear. When Waldo Leland put forward the scheme of the American Council of Learned Societies for cataloguing the "foreign" or "classical and medieval" manuscripts throughout the US, he must have been knocking at an open door: Putnam would surely have welcomed such a venture, and he would have been encouraged in this view both by Richardson and, presumably, by his own Chief of Manuscripts, Professor J. Franklin Jameson (formerly of the Carnegie Institution). Leland's scheme duly became known as 'Project C.' The four thousand or more letters of enquiry for which W. J. Wilson was responsible were all sent in Putnam's name, which must also have given prestige to the project. Only one owner-who one may guess was a private individual—declined to cooperate. ${ }^{11}$

\section{The Completion of the Census}

The Census was published in three volumes, by H. W. Wilson of New York, in 1935-1940. Its first two volumes total 2,343 pages of text, beside which the third volume, with the various indexes, seems insubstantial, even short, at 222 pages. It provides summary descriptions of about fifteen thousand items, mostly codices but also hundreds of individually described medieval and Renaissance deeds and illuminated leaves, as well as a few entries for

10 Ernest Cushing Richardson, Union World Catalog of Manuscript Books, 6 vols. (New York: Wilson Co., 1933-1937).

11 S. de Ricci with the assistance of W. J. Wilson, Census of Medieval and Renaissance Manuscripts in the United States and Canada, 3 vols. (New York: Wilson, 1935-1940), 1:ix. 
whole collections of an archival nature. In England, the pattern for the cataloguing of medieval manuscripts was set by M. R. James's various works (especially for the Cambridge colleges), and these had a cut-off date no later than about the 1530s; but the Census comes down to ca. 1600, or, in the case of the Folger Shakespeare Library, ca. 1625. (At the Folger, it would have been perverse to have had an earlier cut-off date, given that Shakespeare himself died only in 1616.) De Ricci actually hated excluding anything, and had even written entries for such late documents as the original manuscript (1814) of the "Star Spangled Banner" (owned by the Maryland Historical Society, Baltimore); that was ejected, by order, at the proof stage. A small number of seventeenth- and eighteenth-century manuscripts remain, especially in the hundred-page-long list of the Walters manuscripts at Baltimore. $^{12}$

It can hardly be denied that the Census is a work of rigor and scholarship. It is inclusive (almost to a fault), and de Ricci's effort to track down and put before readers the secondary literature for each item was unprecedented (and has rarely been followed, even in recent years). De Ricci took particular trouble to establish each manuscript's provenance. David Pearson, in his handbook Provenance Research in Book History, ${ }^{13}$ has noted of the Census: "Provenances noted in the text, although not exhaustively." As a criticism of the Census this seems perverse: its details of provenance are one of its strongest features. They are quite exceptionally full and were worked out by de Ricci with great skill. Indeed, they are far fuller than those given in such modern catalogues as the exceptionally fine Medieval Manuscripts in British Libraries, compiled largely by the late Neil Ker and published in five volumes between 1969 and 2002. ${ }^{14}$ Moreover, de Ricci used his own knowledge of book sale catalogues and dealers' catalogues to reconstruct

12 De Ricci, Census, vol. 1: Walters Art Gallery MSS 362-68, 414, 420, 422, 425, 489, 499, 530, 534-36, 538, 550, 552-55.

13 David Pearson, Provenance Research in Book History: A Handbook (London: British Library, 1994), 271; repeated in the amended reprint (London: British Library, 1998), same page.

14 De Ricci's and Ker's approaches are compared by Richard W. Clement, "Cataloguing Medieval and Renaissance Manuscripts: A Review Article," Library Quarterly 55 (1985): $316-26$. 


\section{Ramsay: Towards a Universal Catalogue of Early Manuscripts}

Ramsay, Towards a Universal Catalogue of Early Manuscripts | 79

the provenance of a vast number of manuscripts that bore no visible clue to their previous ownership.

His working method was to carry out a visual inspection of a library's collection at great speed, jotting down merely such external signs of former locations and ownership as owners' inscriptions, bookplates, and every miscellaneous jotting of number and price, as well as the nature and type of the binding, number of leaves or pages, and of course the title or contents. ${ }^{15}$ At his leisure, when back in Paris, he could then work out in whose ownership each manuscript must have been-and by definition, for a medieval or Renaissance manuscript, this must have been in Europe for the greater part of the book's existence. This was a working method that could only be carried out by someone with ready access to a vast number of auction and dealers' catalogues, and who was blessed with an exceptionally retentive memory, so that he could extrapolate what a particular book's trajectory through time must have been. ${ }^{16}$ Some subsequent scholars who have been faced with the task of cataloguing the same manuscripts have paid tribute to de Ricci's skill in his self-imposed task. For the Huntington Library, for instance, the more recent-and very capable-cataloguer of its medieval and Renaissance manuscripts, Consuelo Dutschke, remarks in the introduction that the Library's accessions register begins only in 1925, that she owes much of her post-Renaissance information to the Census, and that for the few manuscripts that de Ricci for some reason omitted, "we have almost no information of the manuscript's history." De Ricci did not initially have such information either, but he worked it out from his own shelves and slip indexes.

The Census is certainly not faultless. De Ricci's methodology entailed working out the provenances—and, one suspects, some other details—from

15 Some of his expertise in detecting the value for provenance research of the miscellaneous marks (e.g., inscriptions, prices, and other jottings, as well as bookplates and bindings) that are found in early manuscripts was set out in his Sandars lectures, delivered at Cambridge in 1929: Seymour de Ricci, English Collectors of Books and Manuscripts, 1530-1930, and Their Marks of Ownership (Cambridge: Cambridge University Press, 1930).

16 Cf. E. P. Goldschmidt, “Seymour de Ricci, 1881-1942," The Library, 4th ser., 24

(1943-1944): 187-94. 
the book trade's earlier descriptions of the manuscripts, and inevitably he was liable to repeat those catalogues' misidentifications and other mistakes. Exceedingly few of his provenance details have been faulted, however. Annotations that he entered in his own copy of the Census (now in the staff offices of the department of manuscripts of the Bibliothèque nationale de France) show that he reproached himself for not spotting one or two provenance details of manuscripts in the Pierpont Morgan Library-but these omissions were failures to make informed deductions, not failures to spot visual clues, internal or external.

It is also true that although a very large proportion of the private owners of manuscripts that were described in the Census sent these to the Library of Congress (an operation that was carried out without the loss of a single one), neither de Ricci nor his assistant, W. J. Wilson, seems to have compared their texts with those of existing printed editions. That might be seen as a counsel of perfection, however. The compilers of the British Library's Royal Manuscripts catalogue (1921) engaged in such comparison, ${ }^{17}$ but it has hardly been followed since. Ker did not think it practicable for his British union catalogue, Medieval Manuscripts in British Libraries. For the Census it must have been ruled out both by shortage of time and by the fact that very few libraries will have possessed the requisite printed editions.

There are also a few striking mistakes of the sort that are liable to slip through in any major work carried out on the scale of the Census. For instance, an item in the Library of Congress itself has an entry that reads "Biblia. Vellum. 14th century, 4 folios only," but this item was actually four leaves from the Bible that was printed by Fust and Schoeffer in $1462 .{ }^{18}$ De Ricci, the undisputed expert on early Mainz printings, simply cannot have seen the leaves in question. Such outright mistakes are exceedingly rare, however.

De Ricci tried to forestall criticism of his work's general formatting and presentation - in effect, the summary nature of the descriptions-by publishing specimen entries in advance (as in the Bulletin of the New York Public

17 George F. Warner and Julius P. Gilson, Catalogue of Western Manuscripts in the Old Royal and King's Collections, 4 vols. (London: Trustees of the British Museum, 1921).

18 De Ricci, Census, 1:219. 


\section{Ramsay: Towards a Universal Catalogue of Early Manuscripts}

Library, in 1930 ${ }^{19}$ and by consulting widely. He would not allow his work to be termed "catalogue," and was apprehensive even about calling it a census, in some ways preferring the word "hand-list," while nonetheless feeling that this term could not be used of a work that actually covered many different locations and at slightly varying levels of detail. ${ }^{20}$

The Census did not have the smoothest of passages. Working for two committees, as de Ricci in effect was-committees within the Library of Congress and the American Council of Learned Societies-did not always make for an easy passage. Each side had its own agenda. The assistant whom the Library of Congress had provided for the project, W. J. Wilson, did not get on well with de Ricci: the two men were of very different temperaments. One of Wilson's referees or backers, Professor Kirsopp Lake of Harvard, once wrote: "I have always thought of him as a man of distinguished ability, who was deprived of an opportunity by lack of means and a certain sensitiveness of theological conscience which hindered his advancement in denominational schools." ${ }^{21}$ De Ricci, by contrast, was self-assured and had never known poverty. Wilson could scarcely deny de Ricci's ability to detect and set out the history and constituent texts of each medieval or Renaissance manuscript, or his faultless Latin and Greek; but he did increasingly take to complaining to Putnam, Leland, and even casual correspondents about the slow speed of the venture and de Ricci's dilatoriness, as he saw it, in the matter of proof correction. It was unfortunate for de Ricci's reputation that all the official annual reports on the work for both the Library of Congress and the American Council of Learned Societies were written by Wilson, who at times did not hide his feelings about de Ricci.

De Ricci did not help matters by his preference for working on his own, at home, in Paris. He did indeed wish to examine every manuscript himself,

19 S. de Ricci, "A List of Medieval Manuscripts in the New York Public Library," Bulletin of the New York Public Library 34 (1930): 297-322.

20 He had used the term "hand-list" for a much more limited exercise a few years previously: Seymour de Ricci, "A Handlist of Latin Classical Manuscripts in American Libraries," Philological Quarterly 1 (1922): 100-108.

21 Letter of W. G. Leland to H. Putnam, Librarian of Congress, 16 November 1932: carbon copy in Library of Congress, Manuscripts Division, Archive of American Council of Learned Societies, B.22. 
perhaps also making it all too evident to Wilson that he did not trust him to wring out of a manuscript its fullest discernible history. Until he had some sort of nervous collapse while on a tour of duty in the States in January 1932 (suffering a blackout and loss of memory for half an hour while inspecting the manuscripts in the Detroit Public Library), he maintained a punishingly active timetable so as to achieve his proposed rate of work. ${ }^{22}$ Falconer Madan, his approximate contemporary, aimed to produce a "summary catalogue description" of each manuscript in the Bodleian Library, Oxford, in no more than about twenty-five minutes; it seems probable that de Ricci aimed for something similar. ${ }^{23}$ At the Folger Shakespeare Library in Washington, DC, Giles Dawson, who was in effect the deputy librarian there, recorded that when de Ricci worked through its collections in November and December 1932, he offered to find for de Ricci the record of how Mr. Folger had acquired each item. "But," wrote Dawson, "he declined, saying that he could do that, and do it more quickly, when he got home." 24 In just thirty or forty days, de Ricci got through the entire Folger collection: what emerged a year or so later as 169 pages of proof, with entries for over one thousand items. This was a pace exceeding even that of his time at the Huntington Library, in 1931, where in two months he checked his predrafted entries for the collection, resulting in just over one hundred pages of printed text with slightly more than five hundred entries.

Unfortunately for de Ricci, the very speed with which he was known to work when it was a matter of examining and describing manuscripts

22 E. C. Richardson noted approvingly that "an exceptional expert like M. DeRicci [sic] can do actual cataloging [of manuscripts] at the rate of sixty or seventy a day in large collections": Union World Catalog of Manuscript Books, 6:26.

23 In responses to the Curators (governing body) of the Bodleian Library, 28 May 1890, about the cataloguing of manuscripts, Madan, who was Sub-Librarian, said that he allowed twenty-five minutes per manuscript, or fifteen minutes if the manuscript was already described in the 1697 catalogue; his junior, W. D. Macray, said that he took half an hour. See further R. W. Hunt, ed., Summary Catalogue of Western Manuscripts in the Bodleian Library, vol. 1, Historical Introduction and Conspectus of Shelf-Marks (Oxford: Clarendon, 1953), lxvi (ex inf. Martin Kauffmann).

24 Giles E. Dawson, "History of the Folger Shakespeare Library, 1932-1968," unpublished typescript (ca. 1994), ch. [3], p. 12. 


\section{Ramsay: Towards a Universal Catalogue of Early Manuscripts}

had the effect of exposing him to criticism once he was back in Paris, away from the ability to reassure Leland, Wilson, and others that he was actively pressing the printers - for he had insisted on the work being printed by a Parisian firm - to produce more proofs, and that he was then checking these himself. His slightly stilted English, his ever-optimistic reports of his progress and the gradual realization by Leland and others that he was by the mid-1930s already starting to plan and prepare a British equivalent to the Census, combined to turn his paymasters against him. ${ }^{25}$ They responded by trying to pressure him financially, Leland warning him that they would have to start paying Wilson out of the money that had been intended for de Ricci's own honorarium. This threat, which was indeed carried out for several months, did not accelerate the printing and proof-checking of volume 2, and it certainly cannot have helped improve relations between de Ricci and Wilson. Moreover, since Wilson himself faced possible unemployment when work on the Census was finished (although he had also been engaged on another venture overseen by the American Council of Learned Societies, the Catalogue of Latin and Vernacular Alchemical Manuscripts in the United States and Canada), ${ }^{26}$ he was quite ready to lengthen the time that completion of the Census would take.

Completion, indeed, was not just a matter of filling known gaps. The actual process of searching for addenda was still being engaged in even after much of volume 2 was already in proof. For instance, in 1937, Wilson was writing to booksellers, asking them if they could disclose the names of buyers of medieval manuscripts which he and de Ricci knew from a search of the previous year's American Art Association's Anderson Galleries auction

25 Cf. Institute of Historical Research, Fourteenth Annual Report, 1934-1935 (1936), p. 29:

"Report of the Anglo-American Historical Committee, 1934-1935," presented at the Expanded Session, July 1935; and also Institute of Historical Research, Fifteenth Annual Report, 1935-1936 (1937), p. 35. De Ricci's British project had to be put aside after the outbreak of the Second World War; it is described by Joan Gibbs, "Seymour de Ricci's 'Bibliotheca Britannica Manuscripta," in Calligraphy and Palaeography: Essays Presented to Alfred Fairbank, ed. A. S. Osley (London: Faber \& Faber, 1965), 81-91.

26 W. J. Wilson, Catalogue of Latin and Vernacular Alchemical Manuscripts in the United States and Canada, Osiris 6 (Bruges: Secrétariat administratif de l'Union académique internationale, 1939). 
catalogues had been bought by them and, presumably, sold on. Whilst this was commendable proactivity, it was calculated to open up a whole series of new lines of enquiry.

Finally the American Council of Learned Societies and the Library of Congress so far lost patience with de Ricci that they decided to have the volume of indexes drawn up and printed under their own control, in America. De Ricci was of course called on, or volunteered himself, to compile the index of former owners; and, characteristically, he did this gratis. ${ }^{27}$

The year 1937 perhaps marked the nadir in terms of de Ricci's relations with his American committees. The tide soon began to turn, as royalties and appreciative reviews started to come in and there was a gradual but growing awareness of the scale of what had been achieved. There was even a revival of support for one of de Ricci's more remarkable proposals, which he had long urged and which had for a long time been accepted as an element of the Census: a list of "unlocated manuscripts." ${ }^{28}$ Working through American sale catalogues, he had built up a considerable file of notes of medieval and Renaissance manuscripts whose subsequent location he could not trace: it was his very reasonable surmise that these manuscripts were still in North America, somewhere, and would one day resurface. So why not list them, too, making a start on their history, secondary literature, and so forth? Any serious scholar would be glad to know of their existence, even if their present location was at the time unknown. De Ricci's overseers were less keen on the idea, and as work on the index advanced and this volume, too, proved to be taking as many years as the two volumes of text, the "List of Unlocated Manuscripts" was definitively axed.

The index volume was not finally published until 1940. Even before then, however, the Library of Congress had decided that Project $\mathrm{C}$ was effectively achieved and over. By this time, the Library of Congress and the American Council of Learned Societies had initiated half a dozen or more other bibliographic projects, but it cannot be said that any of them resulted

27 He seems also to have raised the funding to cover the extra printing costs that these forty-four pages would require.

28 It was specifically mentioned by one reviewer of vol. 1: Charles H. Beeson, in Modern Philology 34 (1937): 425-27 at 427. 


\section{Ramsay: Towards a Universal Catalogue of Early Manuscripts}

Ramsay, Towards a Universal Catalogue of Early Manuscripts | 85

in anything quite so remarkable as de Ricci's Census. De Ricci's own professional career was almost at an end by this date. He fell ill shortly after the German seizure of Paris in June 1940, and published almost nothing more after this date, although he lived on until December 1942.

\section{The Reception of the Census}

The scholarly response to the Census, as expressed in reviews in the learned journals, was generally laudatory. Most scholars were simply delighted that so many manuscripts with material of interest to them had now been brought to light. Scholars interested in the Renaissance had particularly little possible cause for criticism, as they were used to shorter codicological descriptions than were medievalists; and de Ricci was exemplary in his descriptions of such major collections as those of the Folger Shakespeare Library (one of the last libraries to be visited for the Census) and the Huntington Library.

Only one reviewer seems at the time to have detected actual omissions of documents or whole manuscripts: de Ricci and Wilson had carried out their search with exemplary thoroughness. The relative openness of American private collectors at this date, combined with de Ricci's own reputation as a bookman must have helped enormously-for he was both a member of the Grolier Club in New York (the premier US society for private book collectors) and was the author of a collector's vade mecum, The Book Collector's Guide: A Practical Handbook of British and American Bibliography. ${ }^{29}$ Nevertheless it was a remarkable achievement even at that date to have succeeded in gaining access to so many private collections, large and small, totaling 285. A comparable undertaking would be impossible today.

The one reviewer who remarked on omissions of manuscripts was Lynn Thorndike: he drew attention to what he described as "a considerable number of manuscripts in the Plimpton collection [by then on deposit in Co-

29 S. de Ricci, The Book Collector's Guide: A Practical Handbook of British and American Bibliography (Philadelphia: Rosenbach Co., 1921). 
lumbia University Library, but at the collector's residence on Park Avenue, New York, when examined by de Ricci] which Mr. de Ricci overlooked." ${ }^{30}$ There were in fact just six such manuscripts.

Just a few medievalists expressed regret that de Ricci had not added such details as the incipit (opening words) of each text. Such information was almost never provided in book trade catalogues, nor was it generally given in the catalogues of major research libraries such as the British Museum or the Bibliothèque nationale in Paris. It had, however, been given in the British Museum's most recent major catalogue, that of the Royal Manuscripts, by Sir George Warner and Julius Gilson (1921), and one or two recent scholarly reference books were actually based on the premise that the incipit was the simplest key to the identifications of texts. ${ }^{31}$ A proposal for an international repertory of the incipits of Latin manuscripts had been put forward by the English historian F. M. Powicke at the International Congress of Historical Sciences in 1923 and subsequently elsewhere; the American Council of Learned Societies had itself considered the matter at its annual meeting in January $1925 .{ }^{32}$ On the other hand, no such repertory resulted and it is probably fair to say that the identificatory value of the incipit was only appreciated widely after the publication of Lynn Thorndike and Pearl Kibre's

30 Lynn Thorndike (of Columbia University), review of de Ricci, Census, in American Historical Review 45 (1940): 857-59 at 858. The defect was made good in a rather grudging article by S. A. Ives, "Corrigenda and Addenda to the Descriptions of the Plimpton Manuscripts as Recorded in the De Ricci Census," Speculum 17 (1942): 33-49 (adding six more manuscripts to the Census's 305).

Dorothy Miner, who read the proofs of the entries in vol. 1 for the collection of Henry Walters (of which she was curator), then detected the omission of "a good eighty manuscripts," but she pointed this out in time for their inclusion in the Census. Cf. D. Miner, "Since De Ricci-Western Illuminated Manuscripts Acquired Since 1934: A Report in Two Parts," Journal of the Walters Art Gallery 29-30 (1966-1967): 68-103, and 31-32 (1968-1969): 40-118.

31 E.g., A. G. Little, Initia operum latinorum quae saeculis xiii. xiv. xv attribuuntur: secundum ordinem alphabeti disposita (Manchester: Manchester University Press, 1904). Scholars using the medieval manuscripts in the Bibliothèque nationale in Paris had for some years had access to the MS index to incipits (MS nouv. acq. lat. 2392) that had been compiled by Barthélemy Hauréau (d. 1896).

32 Cf. Bulletin of the American Council of Learned Societies 4 (1925): 27-9. 


\section{Ramsay: Towards a Universal Catalogue of Early Manuscripts}

Catalogue of Incipits of Mediaeval Scientific Writings in Latin (1937); ${ }^{33}$ and this came out only when most of the work on volume 2 of the Census had been completed. ${ }^{34}$

The greatest weakness of the Census was (and is) arguably its physical format. Had it been published in five or six volumes, or at least on far thinner paper, it would have been far more user-friendly from the start, and would not have been liable to be regarded as a rather awkward, lumbering giant. Unfortunately, the way in which its making was funded, with responsibility for its production being shared by de Ricci with both the Library of Congress and the American Council of Learned Societies, and the fact that some (although actually very little) funding had come from advance subscriptions, meant that it was felt to be impossible to increase the number of volumes. As a result, the more that de Ricci found additional manuscripts - and it does appear that in the end he and Wilson dealt with twice as many items as originally anticipated - the more the whole work became overloaded and its ease of use reduced.

\section{The Census in the Context of de Ricci's Life}

De Ricci once declared that he had devoted ten years of his life to the Census. It had originally been funded as a three-year project. He regretted that it had taken such a large amount of his time and resources. The financial return to him was pretty negligible (perhaps no more than $\$ 3,666$ by way of direct honorarium, apart from travel and other expenses), but he almost never referred to the financial side of the project. ${ }^{35}$ In any case, it is far from

33 Lynn Thorndike and Pearl Kibre, Catalogue of Incipits of Mediaeval Scientific Writings in Latin (Cambridge, MA: Mediaeval Academy of America, 1937).

34 The Census had however been able to make a little use of Thorndike's work: the author had sent some galley proofs to Wilson in the spring of 1936, and further use was made (in the Addenda) of the published work. Cf. Library of Congress, Archives of Manuscripts Division, Project C, Container 4, W. J. Wilson's Chronfile, 1937, letter of 16 August 1937.

35 The sum of $\$ 35,000$ was initially budgeted for the project and was provided by the General Education Board, but by the mid-1930s this was recognised as inadequate, a 
clear that he really needed or expected any direct reward from the project, although his private means were limited.

On the other hand, those responsible for overseeing the project, in both the Library of Congress and the American Council of Learned Societies, were exasperated that he seemed to take so long over it when they had made all sorts of promises and undertakings to funding bodies for its speedier completion. Correspondence in the archives of the Library of Congress shows that his patrons felt that de Ricci dragged his heels, especially in the summer months of each year. He simply had too many irons in the fire, and was temperamentally prone to biting off more than he could easily chew. Throughout these years he maintained his usual flow of books and articles. Besides, his journalism formed a necessary (or at least, customary) part of his income.

The overriding problem for both de Ricci and his sponsors was perhaps this: that he was in principle always delighted that his ambitions and plans for the cataloguing of medieval and later manuscripts could be made to coincide with some sponsor's enthusiasm for publishing such a work, but temperamentally he was very far from being a team player. At all times, he had his own agenda, which was for such quests as the tracing of the history of individual manuscripts as elements of past collections. To such tasks he was utterly devoted, and in their pursuit he was single-minded: delays were of little concern to him, if the outcome was an increase in his knowledge of what interested him. Such an outlook inevitably resulted in major fallingsout with his sponsors, quite apart from helping ensure hostile relations between himself and his allotted assistant, Wilson. ${ }^{36}$

None of this could have been guessed in the mid-1920s by the various scholars and librarians to whom de Ricci had presented his plans for

further $\$ 15,000$ then estimated as needed for completion; some of this further funding, perhaps $\$ 10,000$, was provided by the American Council of Learned Societies itself. Wilson seems to have been on a salary of $\$ 4,000$ a year.

36 Years later, Wilson presented his side of the picture, but in rather mellowed form, in his article "Manuscript Cataloguing," Traditio 12 (1956): 457-555, especially at 463-68, 486-87. 


\section{Ramsay: Towards a Universal Catalogue of Early Manuscripts}

a Bibliotheca Manuscriptorum Nova. ${ }^{37}$ He was the mildest of men to meet, personable, and patently a savant to his fingertips. He was a bookman, too, with the requisite knowledge of all aspects of the physical makeup of books (not excluding such finer points as their possible alteration at the hands of the booksellers through whose possession they had passed), and with a keen sense of how their rarity, condition, history, and so forth would determine their value. One tribute to his competence in the antiquarian bookselling world is that he was regarded as an utterly reliable saleroom agent by A. S. W. Rosenbach, the Philadelphia- and New York-based dealer who in the 1920s and 1930s can fairly be described as the leading antiquarian bookseller in the world. De Ricci, that is to say, had a thoroughly practical and hard-headed side, that enabled him to calculate very accurately the costs of printing a book or the effect of currency conversion between the US dollar, the pound sterling, and the French franc. ${ }^{38}$ De Ricci could be most plausibly businesslike. He was, however, so addicted to book history that he probably never really grudged the appalling expenditure of time-and lack of financial reward - that resulted from his involvement in the making of the Census.

37 The title was clearly intended to recall Bernard de Montfaucon's Bibliotheca bibliothecarum manuscriptorum nova (Paris, 1739), in which large numbers of manuscripts were summarily described on the basis of entries derived from existing catalogues.

38 See correspondence between de Ricci and Dr. Rosenbach in the archives of the Rosenbach Library, Philadelphia (in the series R Co. I). 